測定法

最前線の電気化学一測定法の実際

講 座

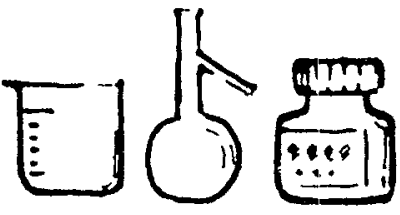

1 はじめに

電極表面を何らかの化学物質で目的意識的に修飾し， 電極に望みの機能をむたせようとする研究，化学修飾電 極に関する研究は益々盛んである. 分子オーダーの精密 さでの修飾が問題にされるようになりつつある.ところ で生体高分子はまさに分子オーダーの精密さでその構造 が機能を規定している．生体高分子修飾電極はこのよう な生体分子自身か持つ特性を電気化学系に持ち込むうと するもので，生体反応を電極反応に共役させるインター フェイシングの問題として大变興味深い. 生体電荷移動 反応の研究，センサーやリアクターへの利用，さらにま たバイオエレクトロニクスへの展開など様々の観点から のアプローチが考えられる。

筆者らは徥来, シトクロムc，フェレドキシン，コレ ステロールオキシダーゼなどのタンパク質, 醳素の電気 化学, 特に水銀電極に吸着時の酸化還元挙動の研究にた ずさわってきた. 生体高分子修飾電極はその一つの展 開としての着想であり,ここで取り上げるのは主として 酸化還元醉素触媒機能をそなえた生体高分子修飾電極で ある。研究の現状は意図した意味での生体触媒機能電極 とはまだかなりの距離があるが，バイオセンサーなどへ の利用は大变注目されている所であり, 醉素と各種電子 伝達メディエータ，また電極自身との電荷移動反応につ いても興味ある知見が得ら抽つるる ${ }^{2.3)}$ ．筆者らの研 究を中心に測定法の実際を含好紹介する。

\section{2 酵素単分子層吸着電極}

酵菜グルコースオキシダーゼ（GOD）を単分子層程 度に固定した電極はディップ コーティング法によって 比較的容易に作成出来る ${ }^{4)}$. GOD 级着電極は $\mathrm{p}-ヘ ゙ ン$ ゾキノン（BQ）のような，電極と级着 GOD との間の 電子移動を仲介出来る化合物（電子伝達メ ディエータ） の存在下でグルコース（Glc）を電解酸化することが出 来る.Fig.1に GOD吸着グラファイト電極を用いて記 録した BQ の対流ボルタンモグラム（Fig.1 A）を示す. Glc を溶液に加えるとその電解酸化に対応するアノー 京都大学㞵学部 (テ606 京都市左京区北白川追分町)

\section{生体触媒機能電極}

\section{池田篤 治}

ディック電流が観察される（Fig.1 B). 反応スキーム は次のように書ける。

$\mathrm{S}+(\mathrm{E}(\mathrm{O}))_{\mathrm{im}} \underset{\mathrm{k} \cdot 1}{\stackrel{\mathrm{k}_{1}}{\rightleftharpoons}}(\mathrm{ES})_{\mathrm{im}} \stackrel{\mathrm{k}_{2}}{\longrightarrow}(\mathrm{E}(\mathrm{R}))_{\mathrm{im}}+\mathrm{P}$

$\mathrm{M}(\mathrm{O})+(\mathrm{E}(\mathrm{R}))_{\mathrm{im}} \underset{\mathrm{k}_{-3}}{\stackrel{\mathrm{k}_{3}}{\rightleftharpoons}}(\mathrm{EM})_{\mathrm{im}} \stackrel{\mathrm{k}_{4}}{\longrightarrow}(\mathrm{E}(\mathrm{O}))_{\mathrm{im}}+\mathrm{M}(\mathrm{R})$

- ne

$\mathrm{M}(\mathrm{R}) \rightleftharpoons \mathrm{M}(\mathrm{O})$

ここで S及び Pはそれぞれ基質と生成物（今の場合 Glc とグルコノラクトン)， M (O) と M (R) は酸化 型及び還元型メディエータ（今の場合 $\mathrm{BQ}$ と八イドロキ ノン), $(\mathrm{E}(\mathrm{O}))_{\mathrm{im}},(\mathrm{E}(\mathrm{R}))_{\mathrm{im}},(\mathrm{ES})_{\mathrm{im}}$ 及び $\left.(\mathrm{EM})\right)_{\mathrm{im}}$ は吸着酵素の酸化型, 還元型, 酵素一基質複合体, 及び 酵素ーメディエー夕複合体を意味する. $\mathrm{k}_{1}, \mathrm{k}_{-1}, \mathrm{k}_{2}, \mathrm{k}_{3}$, $\mathrm{k}_{-3}, \mathrm{k}_{4}$ はそれぞれの段階の速度定数である．Glc は電 極に吸着固定された GOD によって酸化され GOD の活

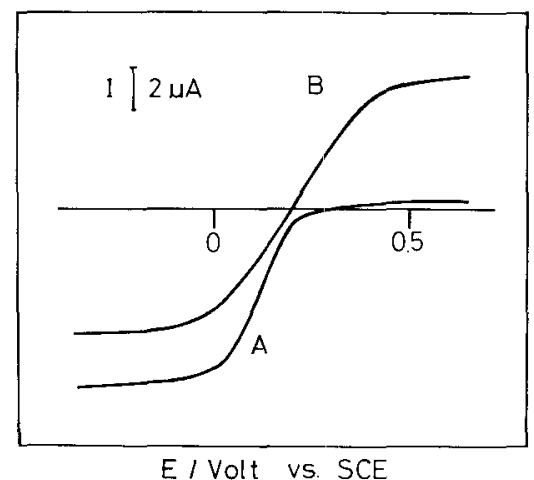

Fig. 1 Voltammograms of (A) $0.5 \mathrm{mmol} / \mathrm{dm}^{3}$ $\mathrm{BQ}$ in $\mathrm{pH} 5.0$ acetate buffer and (B), (A) plus $20 \mathrm{mmol} / \mathrm{dm}^{3} \mathrm{Glc}$ at a graphite disk electrode with adsorbed GOD. The rotation rate of the electrode : $600 \mathrm{rpm}$. 
性中心は還元型になる（1. 式）が M (O) に電子を与え て元の酸化型に戻り，M(O) が $\mathrm{M}(\mathrm{R})$ に還元される (2 式). $M(R)$ の電極酸化 (3式)により酸化電流が 流れ M (O) が再生される. この場合の限界電流 I は次 式で与えられる.

$\mathrm{I}=\mathrm{I}_{\max } /\left[1+\left(\mathrm{K}_{\mathrm{s}} / \mathrm{C}_{\mathrm{s}}\right)+\left(\mathrm{K}_{\mathrm{M}} / \mathrm{c}_{\mathrm{M}}\right)\right]$

ここで

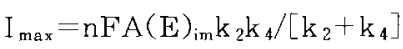

$\mathrm{K}_{\mathrm{s}}=\left[\mathrm{k}_{4} /\left(\mathrm{k}_{2}+\mathrm{k}_{4}\right)\right]\left[\left(\mathrm{k}_{-1}+\mathrm{k}_{2}\right) / \mathrm{k}_{1}\right]$

$K_{M}=\left[k_{2} /\left(k_{2}+k_{4}\right)\right]\left[\left(k_{-3}+k_{4}\right) / k_{3}\right]$

なお $I_{\text {max }}$ は通常の酵素触媒反応における最大速度に対 応し， $K_{s}, K_{M}$ はそれぞれ基質，メディエータのミ八エ リス定数である. $\mathrm{n}, \mathrm{F}, \mathrm{A}$ は電子数, ファラデー定数, 抢よび電極表面積であり，（E） im 単位表面皘あたりの 吸着酵素量, $C_{s}, C_{M}$ は基質, メディエータの電極界面 濃度である。この種の電極では大抵の場合通常の実験条 件下では，基質，メディエー夕の濃度分極は大变小さい ので $\mathrm{C}_{\mathrm{s}}, \mathrm{C}_{\mathrm{M}}$ を母液中濃度に等しいと置くことが出来る. 従ってIの基質濃度,メディエー夕濃度依存性の実験か ら $\mathrm{I}_{\max }, \mathrm{K}_{\mathrm{s}} ， \mathrm{~K}_{\mathrm{M}}$ を求めることが出来る. (5)-(7) 式 から明かなように，此 $\mathrm{I}_{\max } / \mathrm{K}_{\mathrm{s}}, \mathrm{I}_{\text {max }} / \mathrm{K}_{\mathrm{M}}$ はそれぞれ （1）（2）の反応の2 分子反応速度定数に対応した量である. 単分子層程度に醳素を固定化した電極の場合, その特性 はこれらのパラメータの值で評価することが出来る.

\section{3メディエータを保持した酵素固定化電極}

センサーなどへの利用の見地からは、より多くの酵素を 修飾固定した電極が望まれる．またメディエー夕す電極 自体に保持されておれば都合がよい。

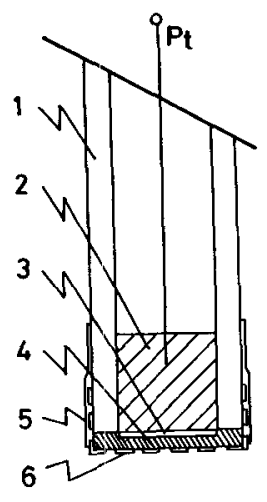

Fig. 2 A film-covered enzyme-immobilized carbon paste electrode containing mediator. 1 , glass tube ; 2 , mediator-mixed carbon paste electrode : 3 , immobilized enzyme layer ; 4 , semipermeable membrane; 5 , heat shrinkable tube ; 6 , nylon net.

\section{1 膜被覆一酵素.メディエータ電極. 作成亡機能評 価法}

筆者らはFig.2 に示すような膜被覆一酵菜固定化一 メディエータ含有カーボンペースト電極を考案しだ． カーボンペーストが良好な電極として働くことは $\operatorname{Adams}^{6)}$ が, またこのペースト中に水に難溶性の redox 種を混合すればこの redox 㮔の酸化還元波が得られる ことをKuwana とFrench ${ }^{7}$ が報告していた。筆者ら は BQのようにメディエータとして働く化合物をべース ト中に混合し，その電極上に酵素をドロップレットエバ ポレーション法で添加した後, 電極老透析膜のような半 透性の膜で被覆した，カーボンペースト中の化合物はそ の一部がペーストバルク中から電極と半透膜の間の醭素 層に溶出してメディエータとして機能することを期待し た. Fig.3の例はこのようなことが可能であることを示 している．膜被覆－GOD固定化－BQ混合カーボンペー スト電極は緩衝液中でサイクリックボルタンモグラムを 記録すると，電極上の GOD 固定層中にトラップされた

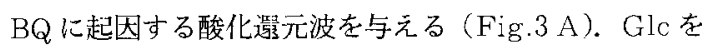
溶液に加えると Fig.3 B の上うな酸化波が現れ, 酵素 層中で式 (1)-(3) の反応が起こっていることがわかる. トラップされた $\mathrm{BQ} の$ 被覆膜を通しての外部液への溶出 はわずかであり，少なくとも1 カ月の間はFig.3のよ

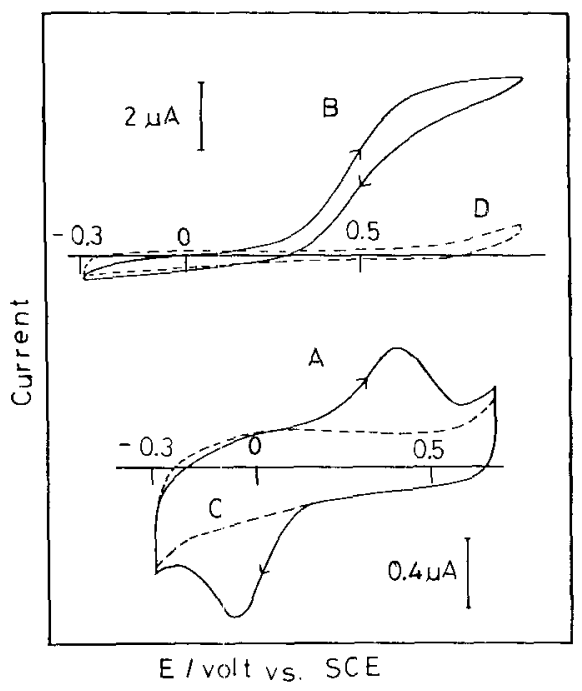

Fig. 3 Cyclic voltemmograms of a film-covered GOD-modified carbon paste electrode containing $\mathrm{BQ}$ in (A) $\mathrm{pH} 5.0$ acetate buffer solution and (B), (A) plus $41 \mathrm{mmol} / \mathrm{dm}^{3}$ Glc. The broken lines $\mathrm{C}$ and $\mathrm{D}$ are the voltammograms obtained with a film-covered GOD-modified carbon paste electrode not containing BQ.Scan rate $50 \mathrm{mV} / \mathrm{s}$. 
うな電気化学応答を示す.

このような系のバイオエレクトロカタリシス反応では 醉素の層はある厚みを持つのでこの層中での基質, メディ エー夕の拡散を考虑する必要がある。ささらに被覆膜を通 しての母液からの基質の拡散と，メディエー夕の母液中 への拡散の過程が含まれるが, 後者の影響はあまり問題 にならない場合が多いのでここでは考えないことにする。 被覆膜の外側の溶液中の濃度分極は溶液を適当に擋找す ることによって避けることが出来る．反応スキームの模 式図をFig.4 に示す。酵素層中の搪散の効果はティ一 レモジュール $\sigma^{2}=\left[\mathrm{k}_{\mathrm{cat}}(\mathrm{E}) 1 / \mathrm{K}_{\mathrm{s}}\right] /\left[\mathrm{D}_{\mathrm{s}} / \mathrm{l}\right]$ の值で評価

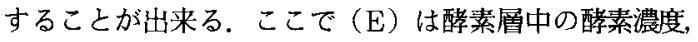
lは醉素層の厚さ，Dは搪散係数で添え字 $\mathrm{s}$ は基質を意 味する、メディエー夕 M に対しても同様である，S，M のいずれかが大過剩の場合, 限界電流Iの基質またはメ ディエー夕濃度依存性は比較的容易に数值計算によって 求めることができ，その結果例えばSについては次の 近似式が使えることが示される ${ }^{8)}$.

$\mathrm{I} / \mathrm{I}_{\max }=\left(\mathrm{I}_{\max }{ }^{\prime} / \mathrm{I}_{\max }\right) /\left[1+\left(\mathrm{K}_{\mathrm{s}}{ }^{\prime} / \mathrm{K}_{\mathrm{s}}\right)\left(\mathrm{K}_{\mathrm{s}} /{ }^{1} \mathrm{C}_{\mathrm{s}}\right)\right]$

ここで $\mathrm{I}_{\max }{ }^{\prime}=\mathrm{nFAk}_{\text {cat }}{ }^{\prime}(\mathrm{E}) 1$ であり， $\mathrm{k}_{\text {cat }}{ }^{\prime}, \mathrm{K}_{\mathrm{s}}{ }^{\prime}$ はそれ ぞれ酵素層中での見かけの触媒定数, 見かけのミハエリ ス定数である. ${ }^{1} \mathrm{c}_{s}$ はFig.4で $\mathrm{x}=1$ での基質濃度を示す. Table1 に示すように見かけの值 $I_{\max }{ }^{\prime}$ と $\mathrm{K}_{\mathrm{s}}{ }^{\prime}$ は $\sigma$ の值の 増加, 即ち拡散の影響が大きくなるとともにそれぞれ真

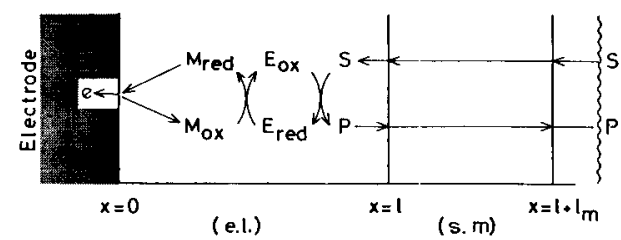

Fig. 4 Kinetic scheme of a biocatalyst electrode with entrapped mediator. e.l. : enzyme layer, s.m. : semipermeable membrane.

Table 1 Values of the ratio of the apparent costants to the true constants as a function of the thiele modulus.

\begin{tabular}{|c|c|c|c|}
\hline$\sigma_{\mathrm{s}}$ & $I_{\max } / I_{\max }$ & & $\mathrm{K}_{\mathrm{s}}^{\prime} / \mathrm{K}_{\mathrm{s}}$ \\
\hline & s.d. & & s.d. \\
\hline 0.17 & $1.001 \pm 0.0003$ & 1.006 & \pm 0.001 \\
\hline 0.50 & $1.005 \pm 0.001$ & 1.055 & \pm 0.005 \\
\hline 1.0 & $1.024 \pm 0.003$ & 1.24 & \pm 0.01 \\
\hline 2.0 & $1.08 \quad \pm 0.02$ & 1.93 & \pm 0.08 \\
\hline 3.0 & \pm 0.02 & 3.2 & \pm 0.1 \\
\hline 5.0 & \pm 0.02 & 7.8 & \pm 0.2 \\
\hline
\end{tabular}

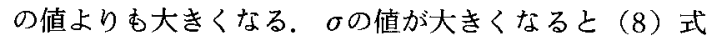

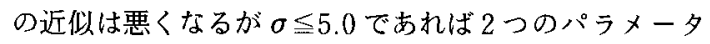
の標準偏差が $5 \%$ 以内で数值計算の結果を近似出来る. Mについてあ同様の式が導かれる。この場合（8）式で $\mathrm{K}_{\mathrm{s}}$ が $\mathrm{K}_{\mathrm{M}}$ に, ${ }^{\mathrm{C}} \mathrm{c}_{\mathrm{s}}$ が $\mathrm{x}=0$ での酸化型 $\mathrm{M}$ の濃度 $\mathrm{c}_{\mathrm{Mox}}$ に置 き変わる， $\mathrm{C}_{\mathrm{Mox}}$ に関する電極反応（式（3））を考慮すれ ば電流一電圧曲線を得る。

（8）式を用いれば実験データから $I_{\text {max }}{ }^{\prime}, K_{\mathrm{s}}{ }^{\prime}$ が求まり, これらの值で電極の特性を評洒することが出来る. 但し 被覆膜の透過性が小さい場合 ${ }^{1} \mathrm{C}_{\mathrm{s}}$ は母液中の基質濃度 $\mathrm{c}_{\mathrm{s}}$ とは等しくない，被覆膜中基質の透過性は次式

$\mathrm{I}=\mathrm{nFAp}\left(\mathrm{c}_{\mathrm{s}}-{ }^{\prime} \mathrm{c}_{\mathrm{s}}\right)$

で表すことが出来る。ここで $\mathrm{p}$ は被覆膜の基質に対す る透過係数である。簡単のため基質の各層間の分配係数 は 1 と仮定したＩの基質濃度依存性は（8）（9）式で表 される、即ち，電極の特性は $I_{\text {max }}{ }^{\prime}, K_{s}{ }^{\prime}, p$ D 3 つのパ ラメータで評価出来る. Fig. 5 に被覆膜の異なるいくつ かの GOD 電極でのI の Glc 濃度依存性を示す，透過 性が低い膜ほど感度は低くなるが直線領域はより高濃度 がわまでのびる．膜透過が律速となる場合，固定化酵素 の活性が少々低下しても電極の特性に影響しない，また 膜の存在はサンプル液による電極の污染を防ぐ効果も期 待でき，センサーとしての機能に寄与するところ大であ る ${ }^{9)}$.

\section{2 センサーとしての利用}

筆者らの電極は簡便, 安価に作成でき，またいろいろ

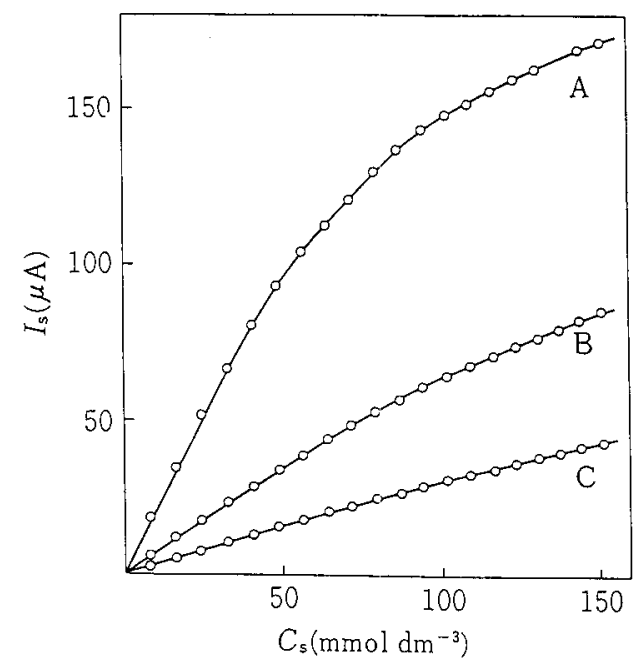

Fig. 5 I vs. $c_{\text {Glc }}$ curves measured at $0.5 \mathrm{~V}$ vs. SCE with film-covered GOD-carbon paste electrodes containing BQ. Film thckness: (A) $50 \mu \mathrm{m}$ nitrocellulose, (B) $50 \mu \mathrm{m}$ dialysis membrane, and (C) $100 \mu \mathrm{m}$ dialysis membrane. 
な酸化還元酵素を用いることができる，Table 2 に使用 可能な酵素グループを示した，大抵の酵素はキノン類や フェロセン類を電子受容体とすることが出来るが, 中に は良好な電子受容体が見つかっていないものもある.

この原理に基づくバイオセンサ一はメディエー夕を用 いるアンペロメトリックバイオセンサーとしてよく知ら れている所であり，筆者らは，Table 2 にあげたような いろいろな醉素を用いて各種糖類や，アルコール，アミ ンなどに対するセンサーを作成している ${ }^{10)}$ ，紙数に制 限があるので，ここではその中で，少し応答の原理を異 にするセンサーのいくつかについてのみ述べる.

（1）－（3）の反応で（3）の反応をストップさせた状 態にすれば時間とともに還元型メディエータ M (R) が電極上の酵素層に蓄積する。一定時間後この蓄積した $\mathrm{M}(\mathrm{R})$ を一気に電解すれば，ストリッピングボルタン メトリーの原理で基質の高感度測定が出来る，細胞膜に 存在する酵素グルコン酸デヒドロゲナーゼ (GADH) について天然の電子受容体ユビキノン（UQ）をメディ
エータとして用いた場合にこのようなことが可能であり， グルコン酸の高感度定量が出来る ${ }^{11)}$.

メディエータのちに注目してみよう。バイオエレクト ロカタリシス反応に扔いてメディエータは酸化還元を繰 り返すのでこのサイクリング反応による増幅が起こる. この点に注目したメディエータの高感度定量が和佐

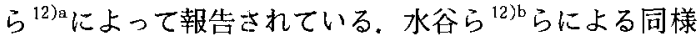
な報告もある、 $\mathrm{p}$ ーアミノフェノールは酵素ジアラー ゼの良好なメディエータとなるが，このあのは多くの加 水分解酵素反応の生成物である. 酵素反応生成物として

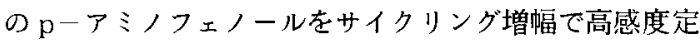
量すればアルカリホスファターゼやガラクトシダーゼな どの加水分解酵素の超高感度アッセイが出来る ${ }^{13)}$.

醉素の中には風变わりなものがある。ある種の微生物 からとれるヌクレオシド酸化酵素（NOD）はラッカー ゼ活性も合わせ持っているが，このラッカーゼ活性はヌ クレオシドが溶液中に存在する時にのみ兒られる。 ヌク レオシド酸化反応に対する良好なメディエータが無いの

Table 2 Oxidoreductases relevant to biocatalyst electrodes.

\begin{tabular}{|c|c|c|}
\hline Enzyme & Reaction & Prosthetic group \\
\hline Group 1 & $\mathrm{~S}+\mathrm{O}_{2} \longrightarrow$ & FAD, FMN, Cu \\
\hline Examples & $\mathrm{P}+\mathrm{H}_{2} \mathrm{O}_{2}$ & Fe-S \\
\hline \multicolumn{3}{|l|}{ Glucose oxidase } \\
\hline \multicolumn{3}{|l|}{ (EC 1.1.3.4) } \\
\hline \multicolumn{3}{|l|}{ Lactate oxidase } \\
\hline \multicolumn{3}{|l|}{ (EC 1.1.3.2) } \\
\hline Group 2 & $\mathrm{~S}+(1 / 2) \mathrm{O}_{2} \longrightarrow$ & $\mathrm{Cu}$, heme \\
\hline Examples & $\mathrm{P}+\mathrm{H}_{2} \mathrm{O}$ & \\
\hline \multicolumn{3}{|l|}{ Ascorbate oxidase } \\
\hline \multicolumn{3}{|l|}{ (EC 1.10.3.3) } \\
\hline \multicolumn{3}{|l|}{ Galactose oxidase } \\
\hline \multicolumn{3}{|l|}{ (EC 1.1.3.9) } \\
\hline Group 3 & $S+M_{o x} \rightarrow$ & FMN, FAD \\
\hline Lixamples & $P+M_{\text {red }}$ & $P Q Q$, home \\
\hline \multicolumn{3}{|l|}{ Fructose dehydrogenase } \\
\hline \multicolumn{3}{|l|}{ (EC 1.1.99.11) } \\
\hline \multicolumn{3}{|l|}{ Glucose dehydrogenase } \\
\hline \multicolumn{3}{|l|}{ (EC 1.1.99.10) } \\
\hline Group 4 & $\mathrm{~S}+\mathrm{NAD}(\mathrm{N} \wedge \mathrm{DP}) \rightarrow$ & - \\
\hline Hxamples & $\mathrm{P}+\mathrm{NADH}(\mathrm{NADPH})$ & \\
\hline \multicolumn{3}{|l|}{ Alcohol dehydrogenase } \\
\hline \multicolumn{3}{|l|}{$(\mathrm{EC} 1.1 .1 .1)$} \\
\hline \multicolumn{3}{|l|}{ Glucose dehydrogenase } \\
\hline ( & & \\
\hline
\end{tabular}

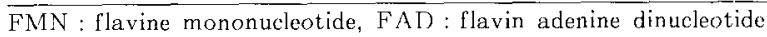

$\mathrm{PQQ}$ : pyrroloquinoline quinone, $\mathrm{M}_{\mathrm{ox}}$ : artificial dye 
で通常のバイオェレクトロカタリシス反応を行わせる事 は出来ないが、ラッカーゼ活性を電極反応之共役させる ことによってヌクレオシドに応答を示す酵素電極が可能 になる. Fig.6に示すようにラッカーゼ反応で八イド ロキノン $\left(\mathrm{BQH}_{2}\right)$ は $\mathrm{BQ}$ に酸化される。 $\mathrm{BQ}$ を電極で 還元すれば八イドロキノンを再生出来る．このラッカー ゼ反応がヌクレオシド酸化反応に依存しているので，こ の電極はヌクレオシドの酸化に対して還元電流伈答を示 す ${ }^{14)}$.

\section{4 生体機能分子，分子集合体のバイオ エレクトロカタリシス活性}

生体触媒機能電極の素材となるのは䤃素だけではない， 例えばシトクロム $\mathrm{c}$ は酵素ではないが電極系と組み合わ せるとナイトライトレダクターゼ様活性を示す，即ち亜 硝酸は触媒量のシトクロム $\mathrm{c}$ が存在すると $\mathrm{pH} 4.0$ で 一0.6ボルトにピークを持つボルタンモグラムを与え， この電位で還元されるようになる，このように電極系と 組み合わせると生体分子本来の機能以外の全く新しい機 能る期待できる。

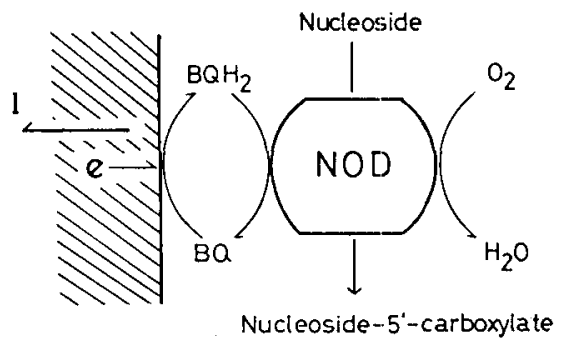

Fig. 6 A scheme of the electron transfer coupling between the electron transfer reaction and the enzymic reaction of $\mathrm{BQ}$ in the presence of nucleoside and oxygen.

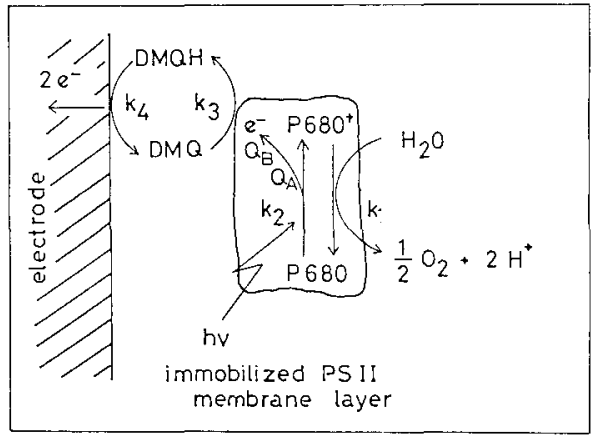

Fig. 7 A scheme of photocurrent response of an electrode with immobilized PS II membrene.
生体では複数のタンパク質が集合して 1 つの機能を発 揮する場合が多い，このような場合機能ユニットをその まま電極系に持ち込むことが考えられる，植物クロロプ ラストの光合成系 II (PSII) を用いると光応答性の電 極が出来る ${ }^{15)}$. Fig. 7 に反応模式図を示す，光照射に よる水加らの酸素発生をジメルベンゾキノン （DMQ）をメディエータとして電極反応と結びつける と, より負の電位で水の電解酸化が起こりそれに応じて Fig. 8 に示すように電極は光応答をする．この系では 基質に対応するものは光であり，3.1で述べた方法で定 量的な解析む可能である.

微生物細胞そのまま利用もできる，Fig. 9 に示すよ うに酰酸菌などの原形質膜に糖やアルコールを酸化する 酵素がある。これらの酵素は基質との反応部位として FADやPQQを有しさらにシトクロムcを含んでいる. 基質を酸化して得た還元当量は呼吸鎖を介して酔素に渡 される。この種の細胞をそのまま電極上に固定してFig. 2 のタイプの電極を作成すると, 電極は糖やアルコール を電解酸化することが出来る。ここでメディエータとし てキノンやへキサシアノ鉄酸（III）イオンが有効である が，これはこれらの化合物が電子の流れを細胞外にバイ パスすることが出来ることを示している.

\section{5 酵素一電極間直接電子移動に基づく 生体触媒機能電極}

これまではメディエー夕を用いる間接的なバイオエレ クトロカタリシスについて述べてきたが, 酵素と電極と の直接電子移動之，それに基づくバイオエレクトロカ夕 リシスも最近注目を集めるようになってきた ${ }^{16)}$ ，筆者

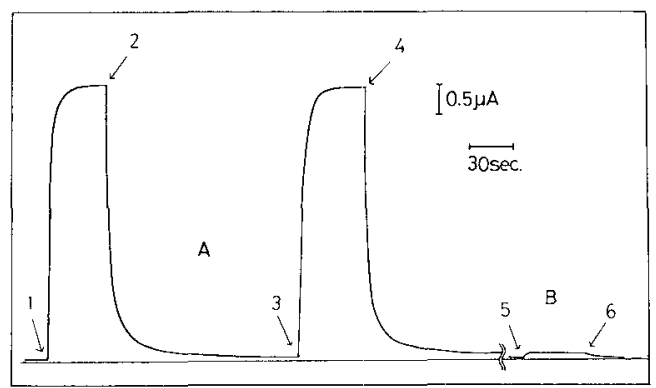

Fig. 8 Photocurrent response of a film-covered PS II membranes-modified carbon paste electrode containing $\mathrm{DMQ}$ at $0.3 \mathrm{~V}$ vs.

$\mathrm{Ag} / \mathrm{AgCl}$ in Tris brfer ( $\mathrm{pH} 7.6$ ) (A) in the absence and $(\mathrm{B})$ in the presence of DCMU, an inhibitor. The light was turned on at the points indicated by 1,3 , and 5 and truned off at 2 , 4 , and 6 . 
らはFig. 9に示した細胞膜結合性の酵甞に注目した ${ }^{17)}$ 。 これらの酵素は複数の酸化還元部位を持っており，膜表 面で基質を酸化しその還元当量を膜内の電子伝達鎖に渡 す. 即ち電子の入り口と出口が異なる。この種の酵素を 基質との反统部位が溶液側に向くように電極表面に配向 吸着させれば，基質からの電子は酵素分子内を電子の通 路として電極に渡されるのではないかと期待した，その ような事が起こっていると思われる一例をFig. 10 に示 す ${ }^{18)}$. 精製した細胞膜アルコール脱水素酵素をディッ プコーティング法で金電極に吸着させると，この電極は

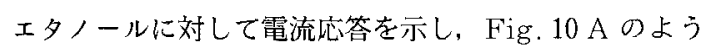

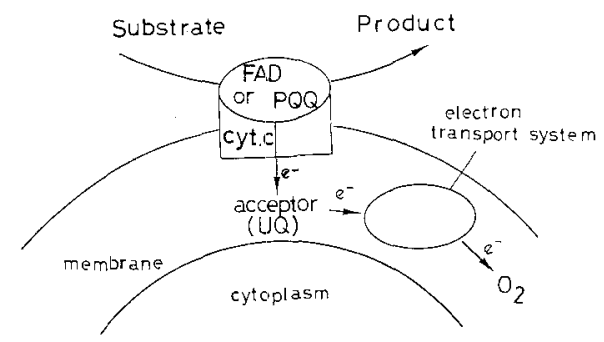

Fig. 9 An oxidoreductase in a bacterial cytoplasmic membrane.

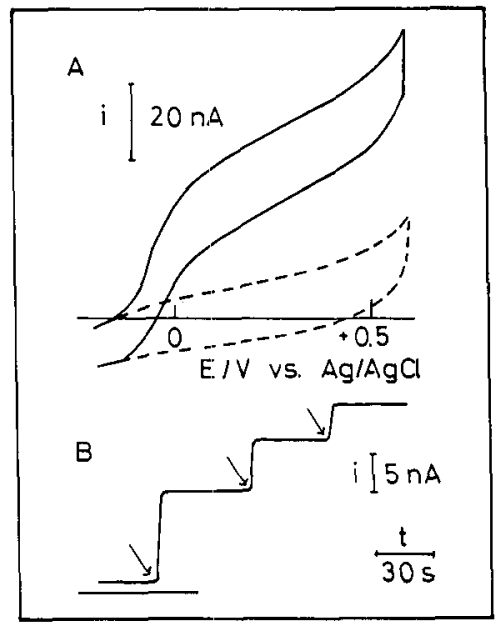

Fig. 10 (A) Cyclic voltammograms at an $\mathrm{Au}$ electrode with adsorbed alcohol dehydrogenase in $\mathrm{pH} 6.0$ buffer solution (broken line) and the buffer solution containing $10 \mathrm{mmol} / \mathrm{dm}^{3}$ ethanol (solid line) at $5^{\circ} \mathrm{C}$ Scan rate, $5 \mathrm{mV} / \mathrm{s}$. (B) Current response to ehtanol of the electrode at $0.2 \mathrm{~V}$. Ethanol in $0.5 \mathrm{mmol} / \mathrm{dm}^{3}$ was successively added at the points indicated by the arrows.
なボルタンモグラムを与える，もちろん裸の金電極では このようなボルタンモグラムは得られない，同じような 性質䘮持った醉索, グルコン酸脱水素醉素, フルクトー 又脱水素酵素でもこのような基質に対する電流応答を示 す，電極も通常のグラシーカーボン，パイロリティック グラファイト, カーボンペースト, 金, 銀, 白金などの 電極を特別な処理なしに用いることが出来る，プロモー ターも必要としない，但し白金電極ではいずれの醉素の 場合もその反応が大変小さい11b,17,18). 限界電流の基質 濃度依存性や電流一電圧曲線の表現式は比較的容易に導 かれるが19)，そのような式に基づいた定量的取扱いに 耐えるようなデータを得るには，安定性を配慮した注意 深い测定が必要である。なお電極上に打ける吸着状態の 解明は今後の問題である. ジアホラーゼやフェレドキシ ンーNADPレダクターゼのような細胞膜周辺酵素もま た電流の大きさは小さいが直接電子移動に基づくバイオ エレクトロカタリシス活性を示す．直接電子移動に基づ くバイオセンサーも可能である、フルクトース脱水素酵 素の市販品（部分精裴標品）をそのまま用いた場合，感 度的にも安定性においても実分析に耐え得るフルクトー スセンサーが可能である ${ }^{20,21)}$.

\section{6 おわりに}

生体機能を電極系に結び付ける筆者らの試みについて, 述べたが，全体にやや舌足らずの説明になってしまった。 足りないところは引用文献を参照して頂ければ幸いであ る.この分野は特に最近多くの人達が関心を持つ所であっ て，多くの研究者によっていろんなアプローチが試みら れており, 電気化学, 分析化学, さらには生化学関係の ジャーナルにも報告が見られる. 今後益々多方面への展 開が行われ，新しいセンサーの開発やバイ才素子の開発 など目的意識を明確にした研究が盛んになるものと思わ れる、筆者自身はあまり実用指向にこだわることなく， 電気化学の立場から生体機能とのインターフェイシング の問題にたずさわっていきたいと思っている.

\section{文 献}

1）下山 真, 池用篤治、ぶんせき，1982. 577.

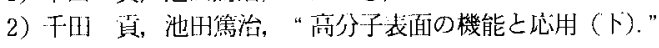
茂義人糄，化学问人，201，(1986).

3) M. Senda anc T.Ikeda, "Bioinstrumentation, "ed by 1.1. Wise, Butterworths, London, 189, (1990).

4) T.Ikeda, I. Kalasho, M. Kamei and M. Senda, Agric. Biol. Chem ., 48,1969 (1984).

5) T.Ikeda, H.Itamada, K.Miki and M.Senda, Agric. Biol. Chem., 49, 541 (1985).

6) R.... Adams, Anal. Chem., 30,1576 (1958).

7) T. Kuwana ar.d W.G. French, Anal. Chem, 36,241 (1964).

8) 'T.Ikeda, K. Miki and M. Senda, Anal. Sci., 4, 133 (1988). 
9) T.Ikeda, H. Hamada and M.Sencia, Agric. Biol. Chem., 50, 883 (1986).

10）総説：池田篤治，食品上業，34，31 (1991)

11) a : T. Ikeda, K.Miki, F. Fushimi and M. Senda, Agric. Biol. Chem.51, 747 (1987), b : 池田篤治，伏見文良, 三木功次郎，千算，分析化学，38. 583 (1989).

12） a : 和传: 保, 秋元健吾, 八尾倿男, 松尾澤夫, 口本化学 雑誌, 1984, 1398. b : F. Mizutani, S. Yabuki and M. Asai, Biosens. Bioelectron., 6, 305 (1991).

13) S. Yamaguchi, S. Ozawa, 'T. Ikeda and M. Senda, Anal, Sci., 8, 87 (1992)

14) T. Ikeda, Y. Hashimoto, M. Senda and Y. Isono, Electroanalysis, 3, 891 (1991).
15) T. Ikeda, M. Senda, T.Shiraishi, M.T akahashi and K. Asada, Chem. I,ett., 1989,913.

16) A. Sucheta, B.A.C. Ackrell, B. Cochran and F.A. Armstrong, Nature, 356, 361 (1992).

17) T. Ikeda, F. Fushimi, K. Miki and M. Senda, Agric. Biol. chem., 52, 2655 (1988).

18) T. Ikeda, S. Miyaoka, F. Matsushita, D. Kobayashi and M. Senda, Chem. Lett., 1992, 847.

19) S. Ando, T. Ikeda, T. Kakutani and M. Senda, Rev. Polarogr. (Kyoto), 26, 19 (1980).

20) T. Ikeda, F. Matsushita and M. Senda, Biosens. Bioelectron., 6, 299 (1991).

21）総説：池田篤治，食品丁業，35，52（1992）. 